\title{
Size and shape variability in the skull of Myotis nigricans (Schinz, 1821) (Chiroptera: Vespertilionidae) from two geographic areas in Brazil
}

\author{
Bornholdt, $R^{\mathrm{a} *}$, Oliveira, $L R^{\mathrm{b} . \mathrm{b}, \mathrm{d}}$ and Fabián, ME. ${ }^{\mathrm{a}}$ \\ aPrograma de Pós-graduação em Biologia Animal, Departamento de Zoologia, Instituto de Biociências, \\ Universidade Federal do Rio Grande do Sul - UFRGS, \\ Av. Bento Gonçalves, 9500, Bloco IV, Prédio 43435, Sala 123, CEP 91540-000, Porto Alegre, RS, Brazil \\ ${ }^{\text {b} G r u p o ~ d e ~ E s t u d o s ~ d e ~ M a m i ́ f e r o s ~ A q u a ́ t i c o s ~ d o ~ R i o ~ G r a n d e ~ d o ~ S u l ~-~ G E M A R S, ~}$ \\ Rua Felipe Néri, 382/202, CEP 90440-150, Porto Alegre, RS, Brazil \\ ${ }^{\mathrm{c} C e n t r o ~ d e ~ E s t u d o s ~ C o s t e i r o s, ~ L i m n o l o ́ g i c o s ~ e ~ M a r i n h o s ~-~ C E C L I M A R, ~}$ \\ Universidade Federal do Rio Grande do Sul - UFRGS, \\ Av. Tramandaí, 976, CEP 95625-000, Imbé, RS, Brazil \\ ${ }^{d}$ Laboratório de Biologia Genômica e Molecular da Faculdade de Biociências, \\ Pontifícia Universidade Católica do Rio Grande do Sul - PUCRS, \\ Av. Ipiranga, 6681, Prédio 12A, sala 172, CEP 90619-900, Porto Alegre, RS, Brazil \\ *e-mail: reborn@terra.com.br \\ Received October 13, 2006 - Accepted March 14, 2007 - Distributed August 31, 2008
}

(With 5 figures)

\begin{abstract}
We present a quantitative analysis of sexual dimorphism and geographic variation in the skull of Myotis nigricans (Schinz, 1821) assessed by geometric morphometrics. Differences in size and shape of skulls were investigated using 30 landmarks plotted on two-dimensional images of lateral and ventral views. Results of geometric morphometrics revealed sexual dimorphism in the centroid size of the skull in both views. Females were larger than males. Nevertheless, there was no sexual dimorphism in skull shape of M. nigricans. Geographic variation was detected in size and shape of the skull. South Brazilian specimens were significantly larger than Ceará specimens only in the lateral view. Differences in skull shape were statistically significant in both views: specimens from South Brazil were brevirostri and presented a more expanded skull in the posterior region while Ceará specimens were longirostri and do not present any expansion in the brain case. Ecological factors for these phenomena are discussed in the text.
\end{abstract}

Keywords: Chiroptera, Myotis nigricans, skull morphology, geometric morphometrics.

\section{Variação de tamanho e forma no crânio de Myotis nigricans (Schinz, 1821) (Chiroptera: Vespertilionidae) de duas áreas geográficas no Brasil}

\begin{abstract}
Resumo
Uma análise quantitativa do dimorfismo sexual e da variação geográfica do crânio de Myotis nigricans (Schinz, 1821) é apresentada através da morfometria geométrica. Diferenças no tamanho e na forma do crânio foram avaliadas através de imagens bidimensionais das vistas lateral e ventral do crânio, onde foram estabelecidos 30 marcos anatômicos. Os resultados indicaram a existência de dimorfismo sexual no tamanho do centróide do crânio para ambas as vistas estudadas. As fêmeas foram maiores que os machos. Contudo, não foi detectado dimorfismo sexual na forma do crânio de M. nigricans. A variação geográfica esteve presente no tamanho e na forma do crânio. Espécimes do Sul do Brasil tiveram tamanho do centróide maior que os espécimes do Ceará apenas na vista lateral. Diferenças na forma do crânio foram estatisticamente significativas em ambas as vistas: os espécimes do Sul do Brasil apresentaram-se brevirostri e com grande expansão na região posterior do crânio, enquanto os espécimes do Ceará apresentaram crânios longirostri e sem expansão posterior da caixa craniana. São discutidos fatores ecológicos para estes fenômenos.
\end{abstract}

Palavras-chave: Chiroptera, Myotis nigricans, morfologia craniana, morfometria geométrica. 


\section{Introduction}

The genus Myotis (Kaup, 1821) has more than 100 species globally widespread (Simmons, 2005). The species are morphologically similar and hardly ever reflect specialization, which may cause some problems in their correct identification (LaVal, 1973; Bogan, 1978; Reduker, 1983; Ruedi et al., 1990; Baud and Menu, 1993; Barquez et al., 1999; Gannon et al., 2001; Ruedi and Mayer, 2001; López-Gonzales et al., 2001; Stadelmann et al., 2004) and leads to a taxonomic complexity of the group. Myotis has had a meaningful evolutionary success, being found in all continents (except in Antarctic), from semi-deserted habitats to sub-Antarctic regions (Ruedi and Mayer, 2001). Most of them are insectivore, even though some fish eater species were registered (Rice, 1998). The species from this genus are able to live together in colonies, sharing space and food, without apparent competitive exclusion (Ruedi and Mayer, 2001; Stadelmann et al., 2004), because morphological similarity does not reflect necessarily ecological similarity (Sauders and Barclay, 1992). According to Benda and Horácek (1995) the morphological variation pattern for this genus provides complex information about taxonomy, adaptation and the history of the distribution of the species as well.

The genus Myotis has 14 species in the Neotropical region (LaVal, 1973), from which six are registered for Brazil: M. albescens (E. Geoffroy, 1806), M. levis (I. Geoffroy, 1824), M. nigricans (Schinz, 1821), M. riparius Handley, 1960, M. ruber (E. Geoffroy, 1806) and M. simus Thomas, 1901 (Simmons, 2005). Myotis nigricans is found from South Mexico (Nayarit and Tamaulipas) to Peru, Bolivia, North Argentina, Paraguay and South Brazil. It is also occurring in Trinidad and Tobago and Lesser Antilles (St. Martin, Montserrat and Grenada) (Simmons, 2005). González (2000) stated that M. nigricans is common in Rio Grande do Sul, including Porto Alegre urban areas. This species has sociable habits and lives in spaces like tree barks, foliages and ceiling of buildings and houses (González, 2000).

Studies about sexual dimorphism and geographic variation from M. nigricans are scarce. LaVal (1973), who is a pioneer in the research about morphological variation of this species, suggested that $M$. nigricans should present differences among populations from different geographic areas in South America. Nevertheless, he did not mention any data about sexual dimorphism. Myers and Wetzel (1983), throughout the analyses of body and skull linear measurements, found some evidence of geographic variation among species from Argentina, Bolivia and Paraguay; however no significant differences were found between male and female specimens. Up to now, the studies describing M. nigricans morphology in South America have been exploring just the tradicional morphometrics (linear measurements) and literally no information about the shape changes was presented (Ihering, 1895; Cabrera, 1957; LaVal, 1973; Myers and Wetzel,
1983; Lopez-Gonzales et al., 2001). Besides, very few information is known about sexual dimorphism and geographic variation from this species in Brazil and most of them are related to body size. In this sense, the current study presents the first information about sexual dimorphism and geographic variation on the size and shape of $M$. nigricans skulls, from two Brazilian geographic areas.

\section{Material and Methods}

A total of 120 adult specimens of Myotis nigricans from two geographic areas in Brazil were examined: South Brazil and Ceará state (Figure 1, see Appendix for details).

\subsection{Studied areas}

South Brazil area comprises the states of Paraná, Santa Catarina and Rio Grande do Sul. The examined specimens from this area were collected between 23 and $31^{\circ} \mathrm{S}$ of latitude, mainly in localities covered by the Brazilian Atlantic Forest (see the appendix for a detailed list of the sampling localities). This biome is composed of two major vegetation types: the Atlantic Rain Forest (coastal forest) and the Atlantic Semi-deciduous forest (tropical seasonal forest). The Atlantic Rain Forest covers the mountain chain that runs along the coastline from northeastern to southern Brazil, which includes our sampling areas in Santa Catarina. The Atlantic Semi-deciduous Forest extends across the plateau in the center and southeastern interior of the country (LeitãoFilho and Morellato, 1997; Oliveira-Filho and Fontes, 2000) and covers most of sampling areas in Rio Grande do Sul and Paraná states. This area experiences warm and wet climate, with dry seasons eventually. The temperatures range from $-6{ }^{\circ} \mathrm{C}$ during winter months to more than $30{ }^{\circ} \mathrm{C}$ in the summer season (Morellato et al., 2000; Morellato and Haddad, 2000; Oliveira-Filho and Fontes, 2000).

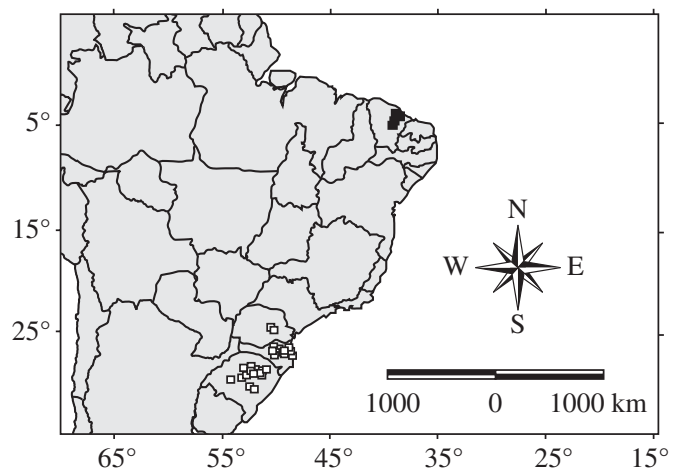

Figure 1. Map presenting the two studied geographic areas with the original localities of Myotis nigricans exemplars. Black square: Ceará State; white square: South Brazil (Paraná, Santa Catarina and Rio Grande do Sul states). 
In the Ceara state, the specimens of $M$. nigricans examined were collected between 06 and $04^{\circ} \mathrm{S}$ of latitude (see the appendix for a detailed list of the sampling localities). The dominant biome is Caatinga, which is a vast xeric biome that covers most of north-eastern Brazil (Mares et al., 1985). This biome is covered by several xeric, deciduous plants associations from dry, open woodland to thorn scrub with cacti ant terrestrial bromelias. In general, the climate conditions are semi-arid, which a variable annual precipitation between 250 and $1270 \mathrm{~mm}$ which falls unpredictably between September and March. There is no permanent water course, only some springs, waterholes and man-made reservoirs (Olmos, 1993). The dryness station remains five to eight months annually and the temperature varies from 27 to $33^{\circ} \mathrm{C}$ (Mares et al., 1985).

\subsection{Material examined}

For this study, the specimens from the following institutions were examined: Zoology Departament from the Instituto de Biociências from the Universidade Federal do Rio Grande do Sul (ZMAM), Museu de Ciências Naturais from the Fundação Zoobotânica do Rio Grande do Sul (MCN), Museu de Ciências Naturais from the Centro Universitário UNIVATES (ZMUMCN) and Universidade de Blumenau (FURB-SLA).

The age group was determined observing the presence of bone or cartilage epiphysis on the metacarpalphalangeal joint from the left forth digit (Burnett and Kunz, 1982; Kunz and Anthony, 1982; Anthony, 1988).

The sexual dimorphism was analyzed just using adult specimens from South Brazil, due to the absence of male specimens from Ceará area. Geographic variation was also analyzed just for adult female specimens for the same reason mentioned above.

\subsection{Geometric morphometrics}

The geometric morphometrics (see Bookstein, 1991; Rohlf and Marcus, 1993; Monteiro and Reis, 1999) were used to analyze sexual dimorphism and geographic variation in skulls of Myotis nigricans. This technique has showed to be objective and efficient when compared to tradicional methods (Zelditch et al., 1995; Rohlf et al., 1996; Rohlf, 1998).

A total of 120 (lateral view) and 119 (ventral view) images of $M$. nigricans skull were analysed (see Table 1). The images were taken using a Nikon Coolpix 4500 digital camera joined to a Nikon SMZ 800 stereo microscope and saved in JPEG format. All the images had an $800 \times 600$ pixels resolution. The skulls were positioned at $90^{\circ}$ from the stereo microscope lenses. A scale was used in this process. Thirty homologous and topologically equivalent landmarks were plotted on the skull in order to describe the size and shape variation. They were digitized using TpsDig1.40 (Rohlf, 2004a). All the landmarks were positioned on the left side of the skull image (Figure 2).

\subsection{Landmarks definition}

Lateral view (Figure 2a): (1) supra occipital basis; (2) skull anterior extremity, leveled to the first incisor
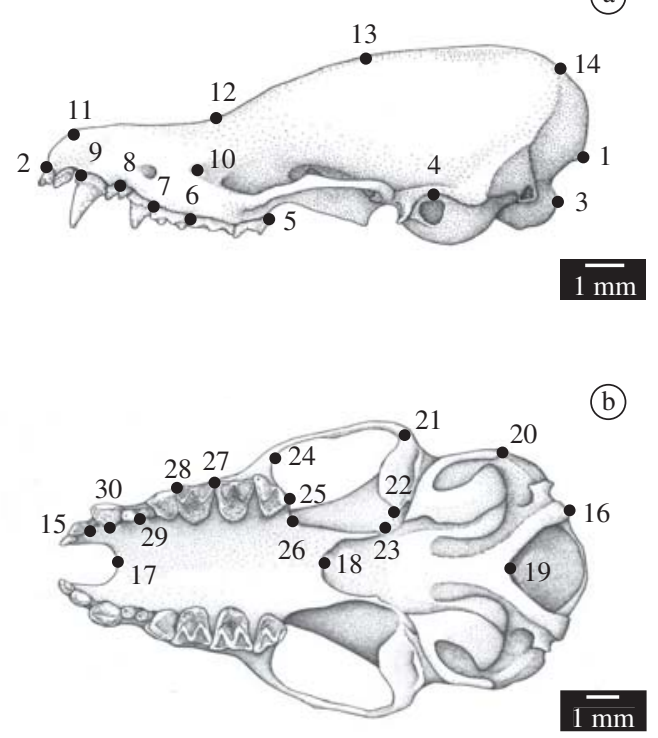

Figure 2. Skull landmarks analyzed in the study (see details in material and methods). a) lateral view. b) ventral view.

Table 1. Number of Myotis nigricans specimens included in the geometric morphometrics analysis (lateral and ventral views), according to the geographic area and gender.

\begin{tabular}{clcc}
\hline $\begin{array}{c}\text { Geographic } \\
\text { area }\end{array}$ & Gender & $\begin{array}{c}\text { Lateral } \\
\text { view }\end{array}$ & $\begin{array}{c}\text { Ventral } \\
\text { view }\end{array}$ \\
\hline South Brazil & Females & 59 & 59 \\
& Males & 48 & 47 \\
Ceará state & Females & 13 & 13 \\
& Males & - & - \\
Total & & 120 & 119 \\
\hline
\end{tabular}

alveolus; (3) post extremity of the occipital condyle; (4) dorsal external auditory meatus; (5) third molar post extremity; (6) alveolar limit between first and second molar; (7) alveolar limit between third pre-molar and first molar; (8) alveolar limit between first and second premolar; (9) canine alveolus anterior extremity; (10) ocular orbit; (11) nasal fossa dorsal extremity; (12) rostrum/ skull congruent point; (13) skull anterior lateral extremity; (14) intersection between interparietal and supraoccipital bone.

Ventral view (Figure 2b): (15) skull anterior extremity, in the level of second incisor; (16) occipital condyle post extremity; (17) premaxillary incisura; (18) palatal incisura; (19) foramen magnum incisura; (20) skull lateral extremity, in the level of auditory region; (21) articular fossa left lateral extremity; (22) articular fossa right lateral extremity; (23) lacerated foramen right lateral extremity; (24) zygomatic incisura; (25) third molar post extremity; (26) mandibular arcade incisura; (27) alveolar limit between first and second molar; (28) alveolar limit 
between third pre-molar and first molar; (29) alveolar limit between first and second molar; (30) canine alveolus left extremity.

To avoid inflation of degrees of freedom related to the bilaterally symmetrical of the ventral view, landmarks were digitized in half of the skull and all the analysis was performed using this configuration.

The coordinates produced by TpsDig 1.40 program (Rohlf, 2004a) from the images (originally recorded as pixels) were converted in millimeters by the multiplication of the established conversion factor pixel $/ \mathrm{mm}$ of each image using the included scale in the image, and then saved in nts format.

Centroid size was calculated using the software TPS Regr 1.28 (Rohlf, 2003), and used as a size variable independent of shape (Bookstein, 1991). Mean centroid size was calculated for both sexes and for both studied regions and compared through Student's $t$-test.

In order to compare shape, the coordinates for each specimen in this study were scaled, aligned and transformed by General Procrustes Alignment (GPA) using the software TpsRel 1.39 (Rohlf, 2004b) with the options $\alpha=0$, projection orthogonal and include uniform component. The GPA method computes a consensus configuration (least-squares Procrustes average configuration) based on the landmark coordinates of all specimens (see Bookstein, 1991, for methodological details). Shape differences between the consensus landmark configuration of each individual specimen were obtained and used to compute a matrix of partial warp scores. Relative warp scores were computed over the covariance matrix of the partial warp scores, therefore being analogous to PCA in the sense that they describe the axes of greater variation in shape for all of the analyzed specimens. The $\alpha$ parameter was set to zero to give the same weight to partial warps in smaller and greater scales (Rohlf, 1993). The partial warps matrix, including the uniform component, was used in a Canonical Variates Analysis (CVA), to describe differences between the populations and in order to confirm patterns previously suggested by the relative warp scores. In this case, if CVA confirms any a priori group, the scores from canonical variant 1 (CV1) and centroid size (CS) of M. nigricans skull were plotted for both views, in order to visualize and evaluate how size and shape contributed for the arrangement of these groups. In addition, thin-plate spline diagrams were generated in order to represent the deformation of skull shape in each population using the software Morpheus et al. (Slice, 1999).

All the statistical analyses of geometric morphometrics were performed using SPSS 11.5 (SPSS for Windows, Lead Technologies Inc, Chicago).

\section{Results}

\subsection{Sexual dimorphism}

Size: The mean of the centroid size was statistically different between male and female specimens from South Brazil (see Table 2) for both studied views. Female skulls were larger than male skulls $(\mathrm{P}<0.05)$.

Shape: For the lateral view, 24 relative warps were generated. The first one explained $25.59 \%$ of the total variation, the second $15 \%$, and the third $11.06 \%$. Together they represent more than $50 \%$ of the skull total shape variation. Scatter plots among the three first relative warps did not show any a priori group formation for the genders.

For the ventral view, 28 relative warps were generated. The first one explained $24.37 \%$ of the total variation, the second $16.18 \%$, and the third $11.5 \%$. Together they represented more than $50 \%$ of total skull shape variation. Scatter plots among the three first relative warps from this view also did not show any a priori group formation for the genders, indicating that there is no differences in the skull shape between males and females of M. nigricans.

\subsection{Geographic variation}

Size: The mean differences in the centroid size were statistically significant in the lateral view (see Table 3), in which specimens from South Brazil were larger than those from Ceará $(\mathrm{P}<0.05)$. Nevertheless, in the ventral view, the mean centroid size was not statistically significant between the studied areas (see Table 3), which indicates a lack of geographic variation in size for this view $(\mathrm{P}>0.05)$.

Shape: 24 relative warps were generated for the lateral view. The first one explained $21.95 \%$ of the total variation, the second $17.71 \%$ and the third $11.93 \%$. Together they represented more than $50 \%$ of the total variation of the skull. The two first relative warps (RW1 and RW2) in the lateral view (Figure 3a) suggested a formation of a priori groups and a partial separation between South Brazil and Ceará specimens along the axis of the second relative warp due to skull shape differences. The CVA of partial warps confirmed the existence of geographic variation in the lateral view, fundamentally related to the change in the skull shape and not related to size (centroid size) (Figure 4). These differences were statistically significant (Wilk's Lambda $=0.470 ; \mathrm{g} 1=4 ; \mathrm{F}=22.62$; $\mathrm{P}<0.0001)$.

The region between the rostrum and the skull congruent point generated the strongest deformation in the lateral view of the skull. The specimens from South Brazil

Table 2. Student's $t$-test results from sexual dimorphism analysis for centroid size in both views of Myotis nigricans skull from South Brazil ( $\mathrm{n}=$ sample number; $\mathrm{t}=\mathrm{t}$ value; d.f. $=$ degrees of freedom; $\mathrm{P}=$ significance).

\begin{tabular}{cccccccc}
\hline View & $\mathbf{n}$ & P Mean (SD) & $\mathbf{n}$ & $\delta^{1}$ Mean (SD) & t & d.f. & P \\
\hline Lateral & 59 & $1.86(0.05)$ & 48 & $1.84(0.04)$ & 2.12 & 105 & $0.036^{*}$ \\
Ventral & 59 & $3.15(0.09)$ & 47 & $3.09(0.08)$ & 3.31 & 104 & $0.001^{*}$ \\
\hline
\end{tabular}

$* \mathrm{P}<0.05$ 

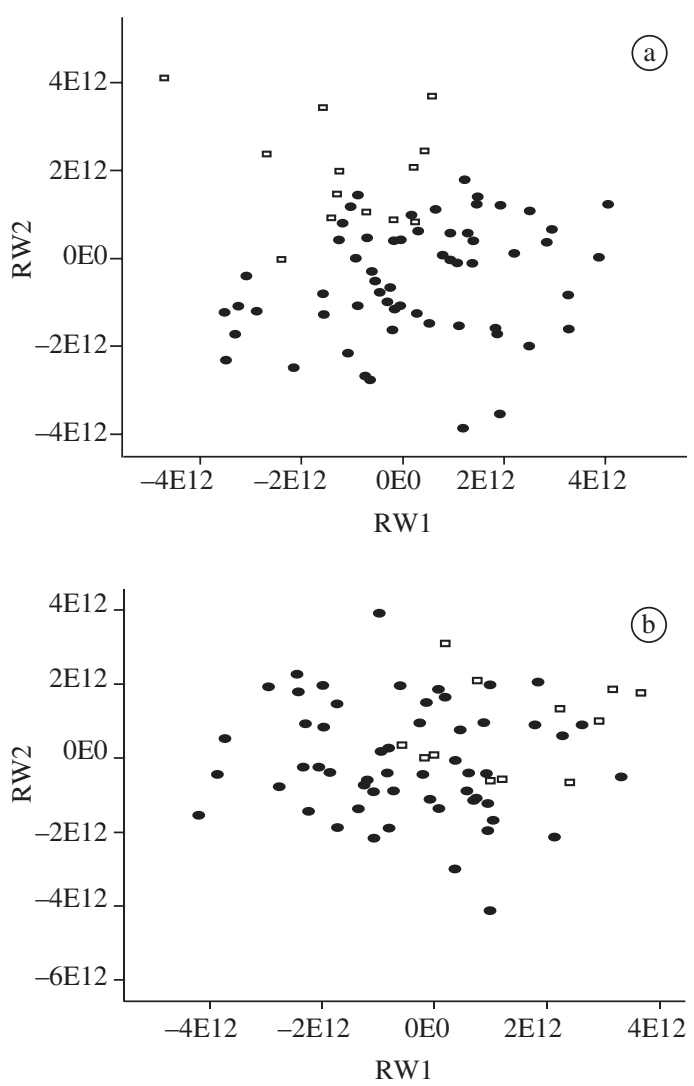

Figure 3. Scatter plot of the first two relative warps scores (RW1 and RW2) of Myotis nigricans female skull on lateral view a) and ventral view b). Black circle: South Brazil; white square: Ceará State.

Table 3. Student's $t$-test results from geographic variation analysis for centroid size in both views of Myotis nigricans female skull of the two studied geographic areas $(\mathrm{n}=$ sample number; $\mathrm{t}=\mathrm{t}$ value; d.f. $=$ degrees of freedom; $\mathrm{P}=$ significance).

\begin{tabular}{|c|c|c|c|c|c|c|}
\hline View & $\begin{array}{cc}\text { n } & \text { South } \\
\text { Brazil } \\
\text { mean (SD) }\end{array}$ & $\mathbf{n}$ & $\begin{array}{l}\text { Ceará } \\
\text { mean } \\
\text { (SD) }\end{array}$ & $\mathbf{t}$ & d.f. & I \\
\hline
\end{tabular}

Lateral 591.89 (0.03) $131.86(0.05) 2.1670 \quad 0.034^{*}$

Ventral $593.15(0.09) 133.19(0.06) 1.67 \quad 700.099 \mathrm{~ns}$

$* \mathrm{P}<0.05$ e $\mathrm{ns}=$ not significant.

are brevirostri, and those from Ceará are longirostri. As a consequence, the brevirostri have a shorter rostrum but a broad and less inclined skull. The longirostri ones have a longer rostrum but a less extensive and abrupt inclined skull.

Twenty eight relative warps were generated for the ventral view. The first one explained $24.61 \%$ of the total variation, the second $16.86 \%$ and the third $10.47 \%$. Together they represented more than $50 \%$ of the total variation of the skull. The two first relative warps (RW1

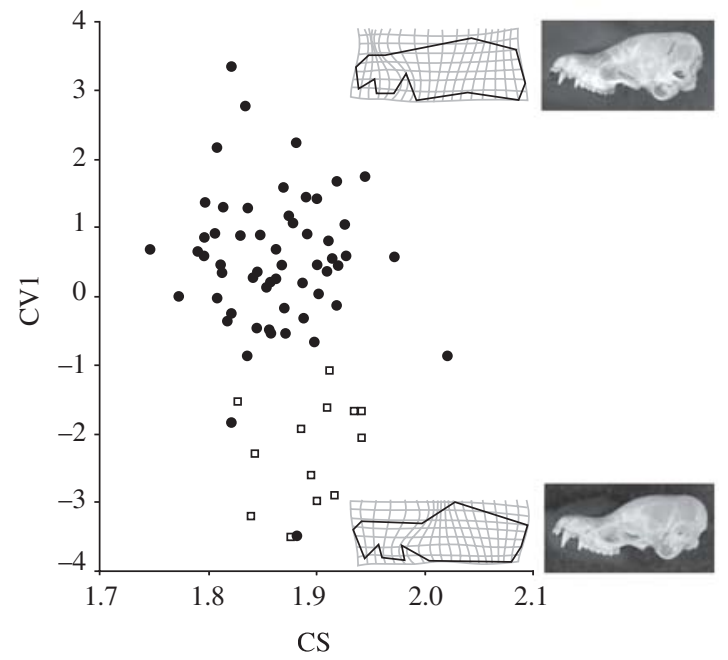

Figure 4. Scatter plot of the scores from canonical variant 1 (CV1) and centroid size (CS) of Myotis nigricans female skull from lateral view. Diagrams represent extreme skull shapes resulting from regression of shape coordinates over canonical scores (effect intensified $3 \mathrm{x}$ ). Photos on the right represent one specimen of each studied geographic area (specimen from South Brazil: ZMUMCN 0265; specimen from Ceará State: MCN 1163). Black circle: South Brazil; white square: Ceará State.

and RW2) in the ventral view (Figure 3b) suggested a formation of a priori groups and a partial separation between South Brazil and Ceará specimens along the axis of the first relative warp due to skull shape differences. The CVA from partial warps also confirmed the existence of two groups for this view, suggesting that the geographic variation in $M$. nigricans is also related to shape changes, but not to size (Figure 5). These differences were statistically significant (Wilk's Lambda $=0.495$; $\mathrm{g} 1=4 ; \mathrm{F}=20.297, \mathrm{P}<0.0001)$.

The extremities of the occipital condyle and the articular fossa regions generated the most evident shape deformation in ventral view. Specimens from South Brazil presented a more expanded skull in the posterior region (in which there is the articular fossa, the tympanic bulla and the occipital condyle) when compared to the same skull region from Ceará specimens.

The lateral view was the most informative for the analysis of geographic variation in $M$. nigricans skulls, because both, centroid size and shape of skull, presented significant differences between specimens from the two studied geographic areas (see Figure 4).

\section{Discussion}

The results for sexual dimorphism suggested that differences between $M$. nigricans male and female skulls were fundamentally related to size and not to shape, with female skulls being larger than male. Myers (1978) stated that bat females of Vespertilionidae are usually larger 


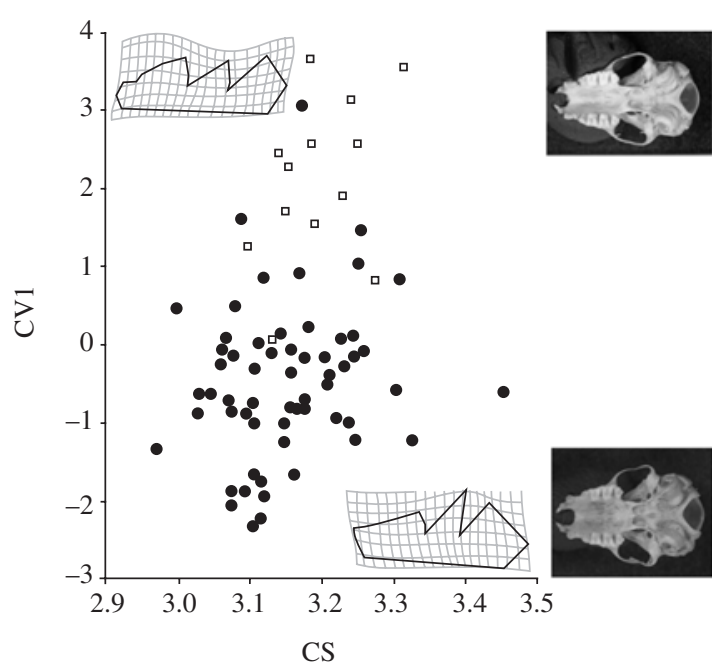

Figure 5. Scatter plot of the scores from canonical variant 1 (CV1) and the centroid size (CS) for half part of Myotis nigricans female skull from ventral view. Diagrams represent extreme skull shapes resulting from regression of shape coordinates over canonical scores (effect intensified 3x). Photos on the right represent one specimen of each studied geographic area (Specimen from South Brazil: ZMAM 0780; specimen from Ceará State: MCN 1148). Black circle: South Brazil; white square: Ceará State.

than males in order to perform appropriately parental care. Females, when pregnant, fly carrying their fetuses. After that they need to take care of the offspring in the colonies. Because of this, a larger size of the body may be favorable to provide a successful reproductive process (Myers, 1978).

Carvalho (1973) commented on the absence of information related to $M$. nigricans' life history. Nevertheless, when analyzing other species from the same genus, Barclay (1991) and Rodrigues et al. (2003) found that, when entering the reproductive period, the females go to reproductive colonies, and there they remain looking after their offspring. For this reason, parental care is, in fact, energetically demanding for females (Kurta et al., 1989) and in this sense a larger size could be favorable.

Our results corroborated the results obtained by Sauders and Barclay (1992). They observed a larger forearm length in females of M. lucifugus and M. volans. In addition, Bogdanowicz and Owen (1996) also found sexual dimorphism in Otonycteris hemprichi skull (Vespertilionidae) using geometric morphometrics. Females presented larger centroid size than males. Overall, the observed differences between male and female skulls of $M$. nigricans presented in the current study confirm the literature data about the existence of sexual dimorphism in vespertilionids related to size.

Size variation in specimens from different latitudes has already been detected in the genus Myotis. Bogdanowicz (1990) foud that, in Europe, specimens of $M$. daubentoni from higher latitudes are larger than those from lower latitudes. Benda and Horácek (1995) obtained the same result for other species of Myotis (M. myotis, M. blythi and M. nattereri) in Paleartic region. Some longitudinal geographic variation patterns were also found in several species of the genus Myotis (Topál, 1971; Myers and Wetzel, 1983; Ruedi et al., 1990; Albayrak and Asan, 2002).

LaVal (1973), based on body size, suggested the existence of a different geographic variation in M. nigricans from Brazil. According to him, specimens from Amazonian Basin were larger than those from Minas Gerais, Rio de Janeiro and São Paulo, regions considered by the author as South Brazil. The data from the current study did not confirm the author's observation. However, it is important to mention that LaVal (1973) only presented the suggestion of geographic variation based on descriptive and qualitative results, which were not statistically tested.

According to Thorpe (1987), there are two suggestions for the existence of geographic variation: (1) current ecology and (2) historical process. The current ecology conditions can be biotic (mimicry, interspecific competition, etc) or physical (substrate adaptation, adaptation for climatic conditions such as Bergmann's rule, etc). The two geographic areas studied are highly differentiated in terms of vegetation, temperatures and also latitude. The Ceará region is located in the arid Caatinga biome in the northeast of Brazil with sampling areas positioned between 06 and $04{ }^{\circ} \mathrm{S}$ (see material and methods for details) and high temperatures varying from 27 to $33{ }^{\circ} \mathrm{C}$ (Mares et al., 1985). While South Brazil sampling areas were in the Brazilian Atlantic forest region, which presents both: a warm and wet climate without a dry season and also a seasonal climate with a relatively severe dry season. The temperatures in this area range from $-6{ }^{\circ} \mathrm{C}$ during winter months to more than $30^{\circ} \mathrm{C}$ in the summer season (Morellato and Haddad, 2000).

In this sense we can speculate Bergmann's rule (Bergammn, 1847), which states that “....races from cooler climates tend to be larger than species of warmblooded vertebrates than races of the same species in living in warmer climates..." (quoted in Mayr, 1963: 319). The usual explanation for this rule is that large animals expend less energy for thermoregulation because of their small surface-to-volume ratio; it is therefore argued that it is more economical for large than for small individuals to live in cold climates (McNab, 1971). Nevertheless, an evocation of this theory to explain our findings could only be reassure if we had examined all the species distribution and found a clinal variation along the different latitudes occupied by $M$. nigricans. In spite of the limitations derived from our restricted sampling areas, we believe that any historical process, could result in population isolation (segregation in the species distribution, for instance) which may lead to a geographic variation pattern associated to specialization.

Based on size and shape geographical variation of the analyzed structures, the occurrence of subspecies 
or distinct species could be suggested. Nevertheless, the small number of male samples coming from Ceará area did not allow an analysis of the geographic variation for this gender. Moreover, there is a lack of knowledge about $M$. nigricans from other regions from Brazil, which would be fundamental for a taxonomic definition. In this sense, we strongly recommend the continuity of this study throughout the analysis of skull and external morphology by traditional morphometrics as well as molecular markers, and mainly to examine specimens along all $M$. nigricans species distribution.

Acknowlegements - We thank to the collection managers: Professor Hamilton Grillo and the biologist Elisangela Mander from Centro Universitário UNIVATES, Professor Sergio Althoff from Fundação Universitária da Região de Blumenau and Dr. Márcia Jardim from Fundação Zoobotânica do Rio Grande do Sul, for the admirable contribution in providing scientific material. We also thank to the anonymous referee for the comments and suggestions. And finally we thank to $\mathrm{CNPq}$ (Conselho Nacional do Desenvolvimento Científico e Tecnológico), which provided the $\mathrm{MsC}$ grant to Renata Bornholdt. This study is part of the dissertation presented by $\mathrm{R}$. B., submitted in partial fulfillment for a MsC degree in Animal Biology at Universidade Federal do Rio Grande do Sul, Brazil.

\section{References}

ALBAYRAK, I. and ASAN, N., 2002. Taxonomic status and karyotype of Myotis capaccinii (Bonaparte, 1837) from Turkey (Chiroptera: Vespertilionidae). Mammalia vol. 66, no. 1, p. 63-70.

ANTHONY, ELP., 1988. Age determination in bats. In KUNZ, TH. (Ed.). Ecological and behavioral methods for the study of bats. Washington, DC.: Smithson. Inst. Press. p. 47-58.

BARCLAY, RMR., 1991. Population structure of temperate zone insectivorous bats in relation to foraging behaviour and energy demand. J. Animal Ecol., vol. 60, p. 165-178.

BARQUEZ, RM., MARES, MA. and BRAUN, JK., 1999. The bats of Argentina. Lubbock: Museum of Texas Tech University. $275 \mathrm{p}$.

BAUD, FJ. and MENU, H., 1993. Paraguayan bats of the genus Myotis, with a redefinition of M. simus (Thomas, 1901). Rev. Suisse Zool., vol. 100, no. 3, p. 595-607.

BENDA, P. and HORÁCEK, I., 1995. Geographic variation in three species of Myotis (Mammalia: Chiroptera) in south of the Western Palearctics. Acta Soc. Zool. Bohem., vol. 59, p. 17-39.

BERGMANN, C., 1847. Ueber die Verhältnisse der Wärmeökonomie der Thiere zu ihrer Grösse. Gottinger Studien, vol. 3, p. 595-708.

BOGAN, MA., 1978. A new species of Myotis from the Islas Tres Marias, Nayarit, Mexico, with comments on variation in Myotis nigricans. J. Mammal., vol. 59, no. 3, p. 519-530.

BOGDANOWICZ, W., 1990. Geographic variation and taxonomy of Daubenton's bat, Myotis daubentoni, in Europe. J. Mammal., vol. 71, no. 2, p. 205-218.

BOGDANOWICZ, W. and OWEN, RD., 1996. Landmarkbased size and shape analysis in systematics of the Plecotine bats. In MARCUS, LF., CORTI, M., LOY, A., NAYLOR, GJP. and SLICE, D. (Eds.). Advances in Morphometrics. New York: Plenum Press. p. 489-501.

BOOKSTEIN, FL., 1991. Morphometric tools for landmark data. New York: Cambridge University Press. 435 p.

BURNETT, CD. and KUNZ, TH., 1982. Growth rates and age estimation in Eptesicus fuscus and comparison with Myotis lucifugus. J. Mammal, vol. 63, no. 1, p. 33-41.

CABRERA, A., 1957. Catalogo de los Mamíferos de América del Sur. Rev. Mus. Cienc. Natur. Bernardino Rivadavia, vol. 4, no. 1 , p. 1-307.

CARVALHO, CT., 1973. Revisão dos vespertilionídeos brasileiros. Silvicultura São Paulo, vol. 8, p. 115-125.

GANNON, WL., SHERWIN, RE., DE-CARVALHO, TN. and O'FARREL, MJ., 2001. Pinnae and echolocation call differences between Myotis californicus and M. ciliolabrum (Chiroptera: Vespertilionidae). Acta Chiropt., vol. 3, no. 1, p. 77-91.

GONZÁLEZ, JC., 2000. Morcegos da área urbana de Porto Alegre, Rio Grande do Sul, Brasil. Divulg. Mus. Ciênc. Tecnol. - PUCRS, vol. 1, no. 5, p. 53-82.

IHERING, HV., 1895. Os mamíferos do Rio Grande do Sul. An. Rio Grande do Sul, vol. 9, p. 41-77.

KUNZ, TH. and ANTHONY, ELP., 1982. Age estimation and post-natal growth in the bat Myotis lucifugus. J. Mammal., vol. 63 , no. 1 , p. $23-32$.

KURTA, A., BELL, GP., NAGY, KA. and KUNZ, TH., 1989. Energetics of pregnancy and lactation in free-ranging little brown bats (Myotis lucifugus). Physiol. Zool., vol. 62, p. $804-818$.

LAVAL, RK., 1973. A revision of the neotropical bats of the genus Myotis. Bul. Natu. Hist. Los Angeles, vol. 15, p. 1-54.

LEITÃO-FILHO, HF. and MORELLATO, LPC., 1997. Semideciduous forests of southeastern Brazil - Serra do Japi. In DAVIS, SD., HEYWOOD, VH., HERRERA-MACBRIDE, O., VILLA-LOBAS, J. and HAMILTON, AC. (Eds.). Centers for plant diversity: a guide and strategy for their conservation. Washington, DC: IUCN/WWF. p. 381-384

LÓPEZ-GONZÁLEZ, C., PRESLEY, SJ., OWEN, RD. and WILLIG, MR., 2001. Taxonomic status of Myotis (Chiroptera: Vespertilionidae) in Paraguay. J. Mammal., vol. 82, no. 1, p. $138-160$.

MARES, MA., WILLIG, MR., LACHE-Jr, TE., 1985. The brazilian caatinga in South American zoogeography: tropical mammals in a dry region. J. Biogeogr., vol. 12, no. 1, p. 57-69.

MAYR, E., 1963. Animal species and evolution. Cambridge: Belknap Press. 797 p.

MCNAB, BK., 1971. On the ecological significance of Bergmann's rule. Ecology, vol. 52, no. 5, p. 845-854.

MONTEIRO, LR. and REIS, SF., 1999. Princípios de morfometria geométrica. Ribeirão Preto: Holos Editora. 189 p.

MORELLATO, LPC. and HADDAD, CFB., 2000. Introduction: the brazilian atlantic forest. Biotropica, vol. 32, p. 786-792.

MORELlATO, LPC., TALORA, DC., TAKALASI, A., BENCKE, CC., ROMERA, EC. and ZIPPARRO, VB., 2000. Phenology of Atlantic rain forest trees: a comparative study. Biotropica, vol. 32, p. 811-823. 
MYERS, P., 1978. Sexual dimorphism in size of vespertilionid bats. Am. Nat., vol. 112, p. 701-711.

MYERS, P. and WETZEL, RM., 1983. Systematic and zoogeography of the bats of the Chaco Boreal. Miscel. Public., p. $1-59$.

OLIVEIRA-FILHO, A. and FONTES, MAL., 2000. Patterns of floristic differentiation among Atlantic forest in southeastern Brazil, and the influence of climate. Biotropica, vol. 32, p. $793-810$.

OLMOS, F., 1993. Diet of sympatric brazilian caatinga peccaries (Tayassu tajacu and T. pecari). J. Trop. Ecol., vol. 9, p. $255-258$.

REDUKER, DW., 1983. Functional analysis of the masticatory apparatus in two species of Myotis. J. Mammal., vol. 64, no. 2, p. $277-286$.

RICE, DW., 1998. Marine Mammals of the world: systematics and distribution. Lawrence: Allen Press. 231 p.

RODRIGUES, L., ZAHN, A., RAINHO, A. and PALMEIRIM, JM., 2003. Contrasting the roosting behaviour and phenology of an insectivorous bat (Myotis myotis) in its southern and northern distribution ranges. Mammalia, vol. 67, no. 3, p. 321-335.

ROHLF, FJ., 1998. On applications of geometrics to studies of ontogeny and phylogeny. Syst. Biol., vol. 47, no. 1, p. 147-158.

-, 2003. TpsRegr. Versão 1.28. New York: State University of New York at Stony Brook, Department of Ecology and Evolution.

-, 2004a. TpsDig. Versão 1.40. New York: State University of New York at Stony Brook, Department of Ecology and Evolution.

-, 2004b. TpsRelw. Versão 1.39. New York: State University of New York at Stony Brook, Department of Ecology and Evolution.

ROHLF, FJ., LOY, A. and CORTI, M., 1996. Morphometric analysis of old world Talpidae (Mammalia, Insectivora) using partial-warps scores. Syst. Biol., vol. 45, no. 3, p. 344-362.
ROHLF, FJ. and MARCUS, LF., 1993. A revolution in morphometrics. TREE, vol. 8, no. 4, p. 129-132.

RUEDI, M. and MAYER, F., 2001. Molecular systematics of bats of the genus Myotis (Vespertilionidae) suggests deterministic ecomorphological convergences. Mol. Phylogenet. Evol., vol. 21 , no. 3 , p. $436-448$.

RUEDI, M., ARLETTAZ, R. and MADDALENA, T., 1990. Distinction morphologique et biochimique de deux espèces jumelles de chauvez-souris: Myotis myotis (Bork.) et Myotis blythi (Tomes) (Mammalia: Vespertilionidae). Mammalia, vol. 54, no. 3, p. 415-429.

SAUNDERS, MB. and BARCLAY, RMR., 1992. Ecomorphology of insectivorous bats: a test of predictions using two morphologically similar species. Ecology, vol. 73, no. 4, p. 1335-1345.

SIMMONS, NB., 2005. Order Chiroptera. In WILSON, DE. and REEDER, DM. (Eds.). Mammal species of the world: a taxonomic and geographic reference. Baltimore: Johns Hopkins University Press. p. 312- 529.

SLICE, DE., 1999. Morpheus et al. @. Dennis E. Slice. New York: Department of Ecology and Evolution, State University of New York at Stony Brook.

STADELMANN, B., HERRERA, LG.,ARROYO-CABRALES, J., FLORES-MARTÍNEZ, JJ., MAY, BP. and RUEDI, M., 2004. Molecular systematics of the fishing bat Myotis vivesi. J. Mammal., vol. 85, no. 1, p. 133-139.

THORPE, RS., 1987. Geographic variation: a synthesis of cause, data, pattern and congruence in relation to subspecies, multivariate analysis and phylogenesis. Bol. Zool., vol. 54, p. 3-11.

TOPÁL, G., 1971. The taxonomic position of Myotis dobsoni (Trouessart, 1879), and some statistical data to the subspecific examination of Myotis blythi. Ann. Historico-Natur. Mus. Nation. Hungarici, vol. 63, p. 383-400.

ZELDITCH, ML., FINK, WL. and SWIDERSKI, DL., 1995. Morphometrics, homology, and phylogenetics: quantified characters as synapomorphies. Syst. Biol., vol. 44, no. 2, p. 179-189. 


\section{Appendix - Specimens examined}

BRASIL, Ceará: Canindé (4² $21^{\prime} \mathrm{S}$ and $\left.39^{\circ} 18^{\prime} \mathrm{W}\right)$,

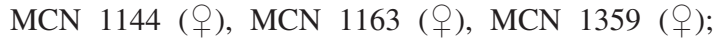
Jaguaruana ( $4^{\circ} 50^{\prime} \mathrm{S}$ and $37^{\circ} 46^{\prime} \mathrm{W}$ ), MCN 1146-1148

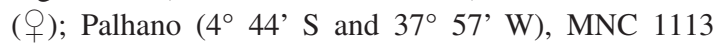
(), MCN 1151-1153 (), MCN 1155 (ㅇ), MCN 1157 (q); Pereiro (6 ${ }^{\circ} 02^{\prime} \mathrm{S} 38^{\circ}$ and $\left.27^{\prime} \mathrm{W}\right), \mathrm{MCN} 1149$ ( ); Paraná: Castro (24. $79^{\prime} \mathrm{S}$ and $50^{\circ} 01^{\prime} \mathrm{W}$ ), ZMAM

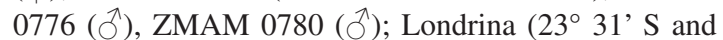

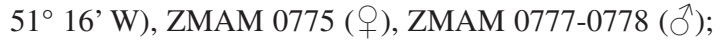
Santa Catarina: Água Doce (26 99' S and $\left.51^{\circ} 16^{\prime} \mathrm{W}\right)$, FURB-SLA 1726 ( $(q)$, FURB-SLA 1730 ( $(9)$; Blumenau ( $26^{\circ} 93^{\prime} \mathrm{S}$ and $\left.49^{\circ} 05^{\prime} \mathrm{W}\right)$, FURB-SLA $1634\left({ }^{\top}\right)$,

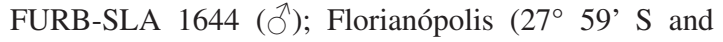
$48^{\circ}$ 54' W), FURB-SLA 0057 ( 9 ), FURB-SLA 0111 (q), FURB-SLA 0238-0240 (ठ̊), FURB-SLA 0241 (), FURB-SLA 0242 (ठ), FURB-SLA 0254-0255 (q), FURB-SLA 0256 (ठ̋), FURB-SLA 0257-0258 (), FURB-SLA 0282 (す), FURB-SLA 0283-0284 (ㅇ),

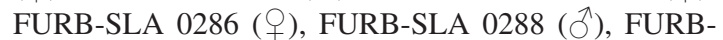
SLA 0289-0290 (), FURB-SLA 0305 (ठ̋), FURBSLA 0306-0308 (q), FURB-SLA 0313 ( ठํ), FURBSLA 0314 (), FURB-SLA 0318 (す̋), FURB-SLA 0320 (す), FURB-SLA 321-0323 (), FURB-SLA 0352-0353 (ठ), FURB-SLA 0360-0361 (ठ̋), FURB-SLA 05520553 (ठ), FURB-SLA 0560 (ㅇ), FURB-SLA 0707 (ㅇ),

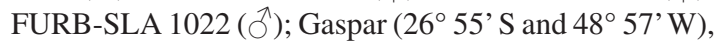
FURB-SLA 0075 ( 9 ); Indaial ( $26^{\circ} 89^{\prime} \mathrm{S}$ and $\left.49^{\circ} 23^{\prime} \mathrm{W}\right)$, FURB-SLA 1740 (ð)), FURB-SLA 1781 (), FURBSLA 1783 (ㅇ), FURB-SLA 1802 (す̊), FURB-SLA $1811\left({ }^{\top}\right)$, FURB-SLA 1823 (9); Jaraguá do Sul (26 29' S and 49 04' W), FURB-SLA 1875 (ठ̊); Joinville
( $26^{\circ} 30^{\prime} \mathrm{S}$ and $48^{\circ}$ 84' W), FURB-SLA 0063 ()); Nova Veneza (28 $63^{\prime} \mathrm{S}$ and $\left.49^{\circ} 49^{\prime} \mathrm{W}\right)$, FURB-SLA 0897 ( $\left.0^{\wedge}\right)$, FURB-SLA 0902 ( 9 ), FURB-SLA 0908 ( + ); Pomerode (26 $74^{\prime}$ S and $49^{\circ} 17^{\prime} \mathrm{W}$ ), FURB-SLA 1220-1222 ( $($ ) ;

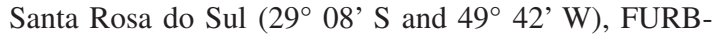
SLA 0914 (ㅇ), FURB-SLA 0918 (ठ゚), FURB-SLA 0920 (†); Rio Grande do Sul: Anta Gorda ( $28^{\circ} 58^{\prime} \mathrm{S}$ and 52 $2^{\circ} 00^{\prime} \mathrm{W}$ ), MCN 0556-0557 (q); Arroio do Meio

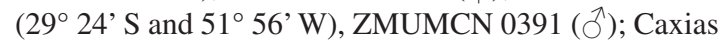
do Sul (29 $10^{\prime} \mathrm{S}$ and $\left.51^{\circ} 10^{\prime} \mathrm{W}\right)$, ZMAM 0078 (우), ZMAM 0079 (ठึ), ZMAM 0080 (q); Dom Pedro de Alcântara (29 22' S and 49 50' W), ZMAM 0195 (q), ZMAM 0196 (ふ), ZMAM 0197 (), ZMAM 0200-0201 (す), ZMAM $0257($ đ), ZMAM 0502 (す); Forquetinha $\left(29^{\circ} 22^{\prime} \mathrm{S}\right.$ and $\left.52^{\circ} 05^{\prime} \mathrm{W}\right), \mathrm{ZMUMCN} 0648$ ( $\left.{ }^{\circ}\right)$; General

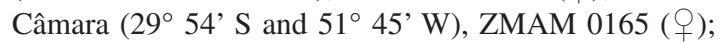

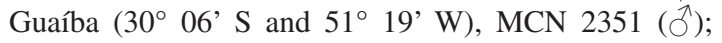
Lajeado (29 $28^{\prime} \mathrm{S}$ and $\left.51^{\circ} 57^{\prime} \mathrm{W}\right)$, ZMUMCN $0225-$ $0226\left(\bigcirc^{\circledR}\right)$, ZMUMCN 0652 (ㅇ); Maquiné (2940’ S and 50²' W), ZMAM ZMAM 0755-0756 (ㅇ), ZMAM

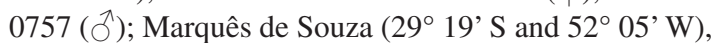
ZMUMCN 617 (ठ̊); Pelotas ( $31^{\circ} 46^{\prime} \mathrm{S}$ and $\left.52^{\circ} 20^{\prime} \mathrm{W}\right)$, ZMAM 0732 (ठ゚), ZMAM 0735 (ㅇ), ZMAM 0740 (す); Putinga (29 $09^{\circ} \mathrm{S}$ and $\left.52^{\circ} 09^{\prime} \mathrm{W}\right), \mathrm{ZMUMCN} 0265$ (†), ZMUMCN 0509 (ठ゚); Santa Maria (29 41' S and 53 49’ W), MCN 0299 (ㅇ), MCN 0301 (đ̋); São José do Herval $\left(29^{\circ} 02^{\prime} \mathrm{S}\right.$ and $\left.52^{\circ} 17^{\prime} \mathrm{W}\right)$, ZMUMCN 0383 (q); São Lourenço do Sul ( $31^{\circ} 21^{\prime} \mathrm{S}$ and $\left.51^{\circ} 58^{\prime} \mathrm{W}\right)$,

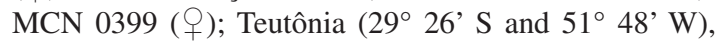
ZMUMCN 0402 (q); Viamão (30 $04^{\circ} \mathrm{S}$ and $51^{\circ} 01^{\prime}$ W), ZMAM 0782 (ㅇ), ZMAM 0783 (ठ̋), ZMAM 0785 $\left(\partial^{\lambda}\right)$. 